\title{
Optimization of stocking density in intensification of mud crab Scylla serrata cultivation in the resirculation system
}

\section{Optimalisasi padat tebar pada pemeliharaan kepiting bakau Scylla serrata dalam sistem resirkulasi}

\author{
Yuni Puji Hastuti ${ }^{1,2 *}$, Kukuh Nirmala ${ }^{1}$, Iman Rusmana ${ }^{2}$, Ridwan Affandi ${ }^{3}$, \\ Wahyu Budi Kuntari ${ }^{1}$ \\ ${ }^{1}$ Department of Aquaculture, Faculty of Fisheries and Marine Science, Bogor Agricultural University \\ Campus IPB Dramaga Bogor, West Java, Indonesia 16680 \\ ${ }^{2}$ Department of Biology, Faculty of Mathematics and Natural Sciences, Bogor Agricultural University \\ Campus IPB Dramaga Bogor, West Java, Indonesia 16680 \\ ${ }^{3}$ Department of Resources Management Living Aquatic, Faculty of Fisheries and Marine Science \\ Bogor Agricultural University, Kampus IPB Dramaga, West Java, Indonesia 16680 \\ *E-mail: yuni_ph2@yahoo.com; yuniha@ipb.ac.id
}

\begin{abstract}
This study aimed to determine optimum stocking density of mud crab Scylla serrata through the applied of different stocking density in every treatment in recirculation system. Experimental design used was complete randomized design (CRD) with three density treatments which were $5(\mathrm{P} 1), 10(\mathrm{P} 2)$, and 15 ind/container (P3). All treatments replicated three times. The crab with the average of body weight $150 \mathrm{~g} / \mathrm{ind}$ cultured in a plastic box $\left(40 \times 30 \times 30 \mathrm{~cm}^{3}\right)$. Crab was cultured within 60 days and were fed two times a day by at satiation method. The result showed that P2 treatment gave the best result of mangrove crabs production performance among all treatments with $73.33 \pm 5.77 \%$ survival rate, $0.68 \pm 0.01 \mathrm{~g} / \mathrm{ind} /$ day absolute growth rate and food conversion ratio $10.11 \pm 0.01$. Treatment P1 gave the good response of stress, it indicated by the lowest glucose of all tretamnets at the level of $31.91 \mathrm{mg} / \mathrm{dL}$ in the end of treatment periods. The water quality during study period was fluctuative as affected by different stocking density in the treatments.
\end{abstract}

Keywords: mud crab, stocking density, production performance

\begin{abstract}
ABSTRAK
Penelitian ini bertujuan untuk menentukan padat tebar optimal kepiting bakau Scylla serrata melalui penerapan kepadatan tebar yang berbeda pada setiap perlakuan dalam sistem resirkulasi. Rancangan penelitian yang digunakan adalah rancangan acak lengkap dengan tiga perlakuan yaitu 5 (P1), 10 (P2), dan 15 ekor/wadah pemeliharaan (P3) dengan tiga ulangan. Kepiting bakau yang digunakan memiliki berat rata-rata 150 g/ekor. Wadah pemeliharaan yang digunakan selama pemeliharaan adalah kontainer plastik yang berukuran $40 \times 30 \times 30 \mathrm{~cm}^{3}$. Pemeliharaan kepiting bakau dilaksanakan selama 60 hari dan diberikan pakan berupa ikan rucah dua kali sehari secara at satiation. Penelitian menunjukkan bahwa perlakuan P2 memberikan hasil kinerja produksi terbaik dibandingkan

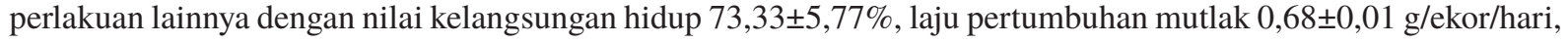
dan rasio konversi pakan 10,11 $\pm 0,01$. Perlakuan P1 menunjukkan respons stres yang baik dengan memiliki nilai kadar glukosa paling rendah dari perlakuan lain yaitu 31,91 mg/dL pada akhir masa pemeliharaan. Kualitas air selama penelitian memiliki nilai yang fluktuatif di setiap perlakuan sebagai efek adanya perbedaan jumlah padat tebar setiap wadahnya
\end{abstract}

Kata kunci: kepiting bakau, padat tebar, kinerja produksi

\section{INTRODUCTION}

Mud crab Scylla serrata is an excellent fishery product having both high economic value and great developmental potential. Its increasing demand on both local and international markets leads to an increment of the production target, reaching up to $188 \%$ (KKP, 2014). Mud crab production mainly relies on wild catches that fluctuates considerably. Thus, there is a need to 
develop a controlled mud crab farming system that can support the continuity of the production.

Mud crab S. serrata production in Indonesia consists of enlargement (or fattening), matured (in terms of eggs) crab production, and soft shell crab. The production is usually done by maintaining crabs in crab box at a density of 1 $\mathrm{crab} / \mathrm{box}$ in ponds (land) or open water around the mangroves. Extensive traditional farming without crab box is carried out at a stocking density of 1 crab per $5-10 \mathrm{~m}^{2}$ of the rearing container/tank. Meanwhile, a dense farming system would only have a stocking density of $1 \mathrm{crab}$ for each 2-5 $\mathrm{m}^{2}$ of the rearing container/tank (KKP, 2014). Mud crab has been widely produced in some coastal (ponds) areas in Indonesia, such as Karawang, Pemalang, Demak, Jepara and other coastal areas, especially those with mangrove forests.

Both land and rearing container efficiencies are needed in order to increase the quality and quantity of the mud crab production. In addition, optimal density and environmental manipulations are also necessary for creating optimal conditions which support growth and production. Suitabke environmental conditions (FAO, 2011) included shallow waters (with muddy ground), temperature $\left(25-35{ }^{\circ} \mathrm{C}\right)$, pH (7.5-9.0), dissolved oxygen $(\mathrm{DO}>5 \mathrm{mg} / \mathrm{L})$, and salinity $(10-25 \mathrm{~g} / \mathrm{L})$. Previous research demonstrated that the optimum salinity for mud crab $S$. serrata optimal growth and survival in a water recirculating system is $25 \mathrm{~g} / \mathrm{L}$ with an optimum pH of 7 (Hastuti et al., 2015; Hastuti et al., 2016).

Mud crabintensive production in a recirculating system is not only a more efficient way of farming but also important for the development of fisheries products (Siahainenia, 2009). The recirlating system is aimed at reusing the rearing water after it goes through filtration, sedimentation and bacterial purification processes in order to maintian bacteria and nitrogen at optimum levels. It is referred to as a closed culturing system, since both environment and media are tailored to the need of the farmed organism (Mulyadi et al., 2014), and it has the advantge of being adaptable to the needs of the farmed organism through various manipulations. The system could be also applied on narrow field in order to intensively increase mud crab production (Schreier et al., 2010). Mud crab stocking density optimization in a recirculating system is one of a breakthrough research in increasing its production.

This study was aimed to determine an optimum stocking density for mud crab production and eveluate its impacts on growth performance. The results of the present study will serve as a reference for further research on the recirculating system.

\section{MATERIALS AND METHODS}

\section{Research design}

A completely randomized design with three treatments (three different stocking densities) was used in this study, consisting of 5 (P1), 10 (P2), and $15(\mathrm{P} 3)$ crabs/container. Each treatment was replicated three times.

\section{Environmental preparation}

As much as nine plastic containers $(60 \times 40 \times 40$ $\mathrm{cm}^{3}$ ) were used in this research. The containers were cleaned with detergent, rinsed (with clean water) and dried, before placing them on rearing shelves and compiled based on the recirculating scheme for each treatment (Figure 1). The recirculating system was aimed at maintaining optimal conditions for mud crab production by reducing the accumulation of feces and feed residues in the rearing containers. Three different filters were used i.e. biological, chemical, and physical (Figure 2). The physical filter consisted of cotton and sand layers (Malang sand), while the chemical filter was made of zeolith stone. Bioball were used as biological filter.

A recirculating system was built for each treatment, thus a total of three recirculating systems were created, and made of three plastic containers and two drums (220 L) that served one as filter and the second as storage for filtered water. Each plastic container represented a replicate in each treatment and container was equipped with two aeration stones $(0.125 \mathrm{~L} / \mathrm{s})$ and six shelters bound together using gutters in a cuboid shape $\left(10 \times 10 \times 10 \mathrm{~cm}^{3}\right)$. The drums were also equipped with water pumps $(60 \mathrm{~W})$ serving to drain water from the filtering containers towards the rearing containers.

Both fresh and sea waters were used in the present study. The latter was brought from Ancol, West Java, at a salinity of $35 \mathrm{~g} / \mathrm{L}$, while tap water (from the Faculty of Fisheries and Marine Science, Bogor Agricultural University) was used as freshwater. Prior to use, water was first sterilized and aerated for 24 hour in order to avoid pathogenic microorganisms and chemicals as well that may harm the tested crab. In order to reach a salinity of $25 \mathrm{~g} / \mathrm{L}$, which is the optimum for mud crab growth performance (Hastuti et al., 2015) 


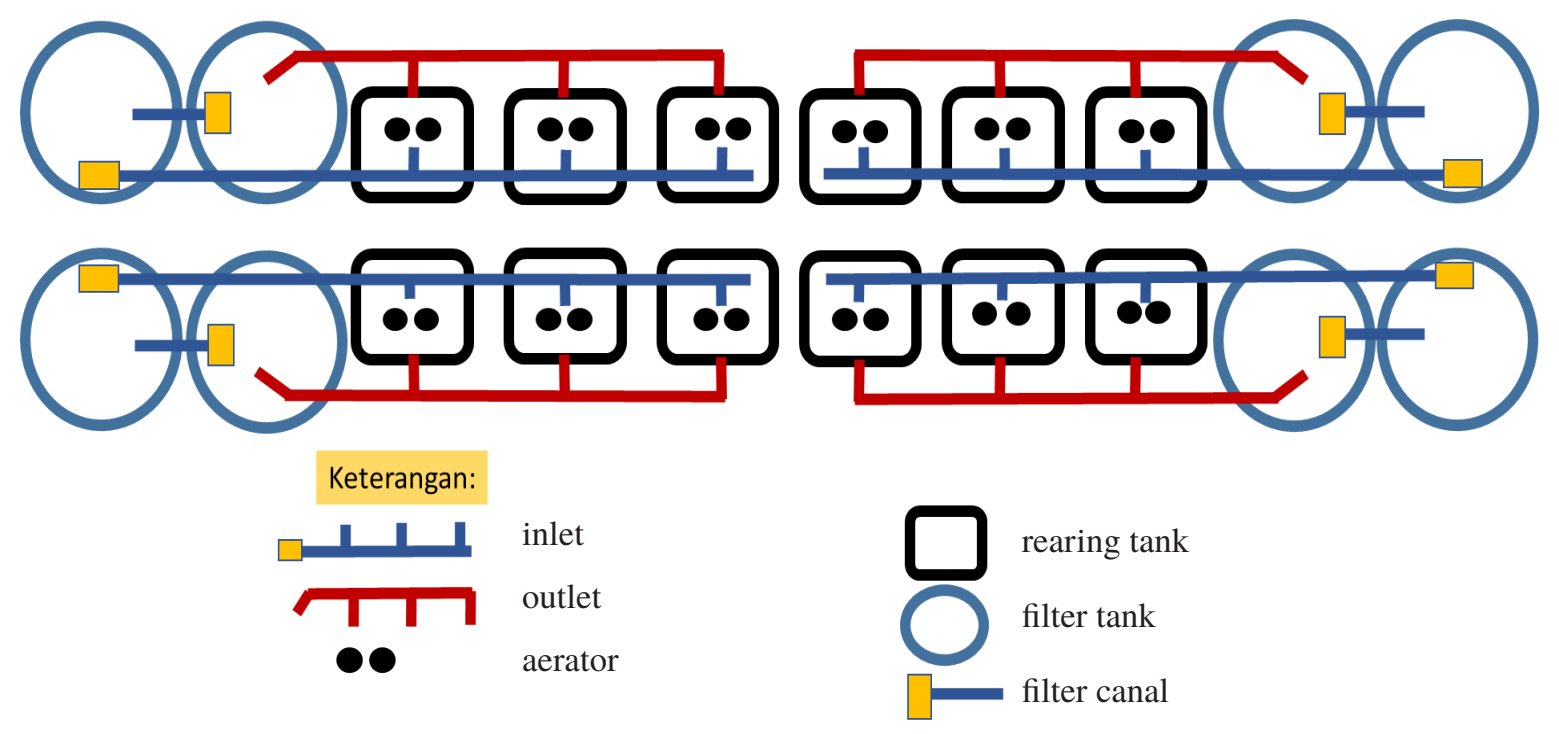

Figure 1. Recirculation scheme.

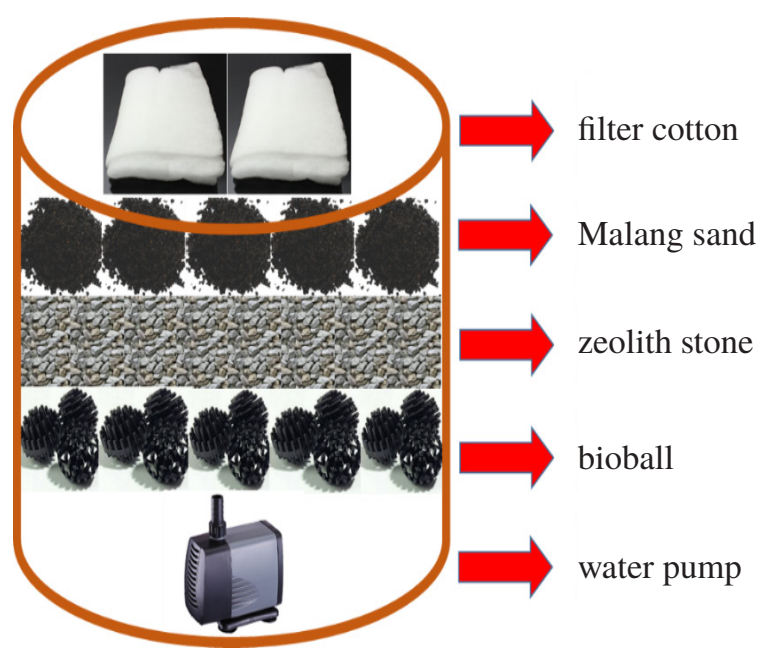

Figure 2. Filtering drum composition.

\section{Preparation and rearing of the tested crabs}

Ninety mud crabs at an average initial body weight of $150 \mathrm{~g}$ were used in the present research. Crabs were brought from Banjarmasin, South Kalimantan. Prior to stocking, crab were acclimatized to a medium saline water $(25 \mathrm{~g} / \mathrm{L})$ for three days, and intial samples such as body weight and carapace width were taken prior to placing the crabs into containers.

Trash fish, derived from fish markets (TPI) in Muara Angke, was used to feed the crabs, which were fed twice daily ( 8 am and $4 \mathrm{pm}$ ) at satiation. The rearing period lasted for 60 days and water quality was maintained at an optimum level by smoothly running the recirculation system and making sure that no parts of both inlet and outlet were clogged. A stable water flow was maintained and $5 \%$ of the water was sponged out once there was waste (feed and feces). The tested parameters are presented in Table 1.

Water quality parameters such as temperature, $\mathrm{pH}$, and water DO were recorded daily ( $8 \mathrm{am}$, $12 \mathrm{am}, 5 \mathrm{pm}$, and $10 \mathrm{pm}$ ), while the others were measured weekly. Production performance parameters were also observed weekly, while stress response parameters were measured at the beginning, middle, and the end of rearing period.

\section{Data analysis}

The data were analyzed and tabulated using Microsoft Excel 2007 and SPSS and presented in forms of tables and graphs. Analysis of variance (ANOVA) with F-test at $95 \%$ of confidence interval was used to analyse data on production, while descriptive analysis was used for stress response and water quality profile. 


\section{RESULTS AND DISCUSSION}

\section{Results}

\section{Production performance}

A 60 days period research on mud crab genrated data on production parameters such as survival rate (SR), absolute growth rate (AGR), and feed conversion ratio (FCR), presented in Table 2. Analysis of variance test (ANOVA) results showed that stocking density had significant effects on production parameters such as survival rate (SR), absolute growth rate (AGR) and feed conversion ratio $(\mathrm{FCR})(\mathrm{P}<0.05)$. No significant differences were observed between $\mathrm{P} 1$ and $\mathrm{P} 2$ treatments, but they significantly differed when compared to P3 treatment in survival rate and feed convertion ratio parameters. The highest survival rates were observed in P1 treatment $(80.00 \pm 0.00 \%)$ and no significantly different with P2 treatment (73.33 55.77). There is no significant differences were observed between P1, P2 and P3 treatments in absolute growth rate parameter $(0.68 \pm 0.02 \mathrm{~g} /$ crab/day, $0.68 \pm 0.01 \mathrm{~g} / \mathrm{crab} / \mathrm{day}$, and $0.66 \pm 0.01 \mathrm{~g} /$ crab/day). P1 and P2 treatments had no significant differences in the FCR value $(10.31 \pm 0.15$ and $10.11 \pm 0.11)$ but they differed significantly when compared to P3 treatment $(9.33 \pm 0.22)$.

\section{Stress response}

Hemolymph glucose levels, which were determined as physiological response parameter of mud crab in each treatment (during the rearing

Table 1. Tested parameters

\begin{tabular}{llcc}
\hline & Parameter & Unit & Measuring tool and method \\
\hline \multirow{2}{*}{$\begin{array}{l}\text { Production } \\
\text { performance }\end{array}$} & Survival rate (SR) & $\%$ & Goddard (1996) \\
& Absolute growth rate (AGR) & g/crab/day & Goddard (1996) \\
& Feed conversion ratio (FCR) & - & Goddard (1996) \\
\hline Stress response & Hemolymph glucose levels & nmol/L & Blaxhall and Daysley (1973) \\
\hline & Temperature & ${ }^{\circ} \mathrm{C}$ & Thermometer \\
& Turbidity & $\mathrm{NTU}$ & Turbidimeter \\
& Dissolved oxygen (DO) & $\mathrm{mg} / \mathrm{L}$ & DO-meter \\
& Biochemical oxygen demand (BOD) & $\mathrm{mg} / \mathrm{L}$ & BOD kit \\
& pH & - & pH-meter \\
Salinity & $\mathrm{g} / \mathrm{L}$ & Salinometer \\
Ammoter quality & mg/L & Spectrophotometer \\
& Nitrite & $\mathrm{mg} / \mathrm{L}$ & Spectrophotometer \\
& Nitrate & $\mathrm{mg} / \mathrm{L}$ & Spectrophotometer \\
& Total organic matter (TOM) & $\mathrm{mg} / \mathrm{L} \mathrm{KMnSO}$ & Titration \\
Alkalinity & $\mathrm{mg} / \mathrm{L} \mathrm{CaCO}$ & Titration
\end{tabular}

Table 2. Production performance of mud crab Scylla serrata at the end of the rearing period

\begin{tabular}{lccc}
\hline \multirow{2}{*}{ Parameter } & \multicolumn{3}{c}{ Stoking densities (ind/container) } \\
\cline { 2 - 4 } & $80.00 \pm 0.00 \mathrm{a}$ & $\mathrm{P} 2(10)$ & $\mathrm{P} 3(15)$ \\
\hline Survival rate $(\%)$ & $754.20 \pm 3.53 \mathrm{a}$ & $1380.10 \pm 110.04 \mathrm{~b}$ & $1370.77 \pm 287.08 \mathrm{~b}$ \\
Biomass $(\mathrm{g})$ & $1849.67 \pm 106.73 \mathrm{a}$ & $3181.00 \pm 332.65 \mathrm{~b}$ & $3826.67 \pm 304.16 \mathrm{c}$ \\
Total consumption feed $(\mathrm{g})$ & $0.68 \pm 0.02 \mathrm{a}$ & $0.68 \pm 0.01 \mathrm{a}$ & $0.66 \pm 0.01 \mathrm{~b}$ \\
Absolute growth rate (g/ind/day) & $10.31 \pm 0.15 \mathrm{a}$ & $10.11 \pm 0.11 \mathrm{a}$ & $9.33 \pm 0.22 \mathrm{~b}$ \\
Feed conversion ratio & & &
\end{tabular}

Numbers on the same line followed by the same letter are not significantly different (at confidence level of $95 \%$ ). 
period) are presented in Figure 3. Hemolymph glucose levels that determined as physiological response parameter of mud crab in each treatment (during the rearing period) are presented in Figure 3. Decreases in hemolymph glucose levels were observed in all treatments at the end of the rearing period. The highest decrease levels were shown in the P1 $(36.71 \mathrm{mg} / \mathrm{dL})$ at the beginning of the rearing, it decreased to $31.91 \mathrm{mg} / \mathrm{dL}$ at the end of rearing. P3 treatment has the lowest decrease levels, it decreased from $37.95 \mathrm{mg} / \mathrm{dL}$ at the beginning of rearing to $36.36 \mathrm{mg} / \mathrm{dL}$ at the end of rearing.

\section{Water quality}

Water quality parameters such temperature, turbidity, dissolved oxygen, biochemical oxygen demand (BOD), $\mathrm{pH}$, salinity, ammonia, nitrate, nitrite, alkalinity, and total organic matter (TOM) are presented in Table 3, and were still within the normal range for mud crab rearing in a recirculating system.

\section{Discussion}

Optimizing mud crabs S. serrata stocking density in a recirculation system was observed to have positive effects on environmental conditions. Indeed, physicochemical parameters are known as ecological factors that could directly affect oxygen consumption, metabolism, reproduction, growth, moulting, hormone production, phagocytosis, osmoregulation, and survival of

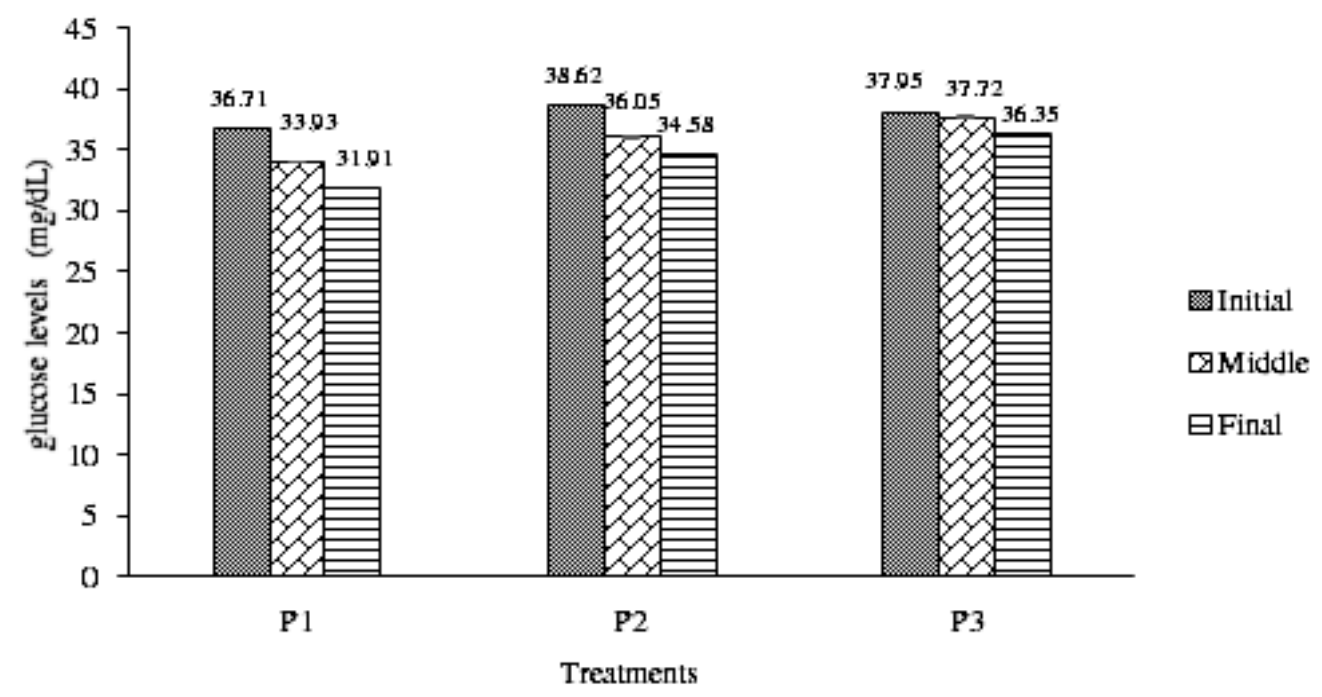

Figure 3. Hemolymph glucose levels in mud crab during the 60 days rearing period. Treatment: 5 (P1), 10 (P2), and $15(\mathrm{P} 3)$ crabs/rearing container.

Table 3. Water quality parameters of rearing crab reared for 60 days

\begin{tabular}{lccc}
\hline \multirow{2}{*}{ Parameter } & \multicolumn{3}{c}{ Stocking densities (ind/container) } \\
\cline { 2 - 4 } & $26-29$ & P2 (10) & P3 (15) \\
\hline Temperature $\left({ }^{\circ} \mathrm{C}\right)$ & $3.5-8.0$ & $25-29$ & $26-29$ \\
Dissolved oxygen $(\mathrm{mg} / \mathrm{L})$ & $0.45-2.70$ & $3.5-8.0$ & $3.5-8.0$ \\
Turbidity (NTU) & 25 & $1.10-3.80$ & $0.80-4.80$ \\
Salinity $(\mathrm{g} / \mathrm{L})$ & $0.0032-0.0144$ & 25 & 25 \\
Biochemical oxygen demand $(\mathrm{mg} / \mathrm{L})$ & $4.69-6.92$ & $0.0032-0.0164$ & $0.0048-0.0144$ \\
pH & $11.46-57.31$ & $11.46-80.23$ & $11.46-68.77$ \\
Alkalinity $\left(\mathrm{mg} / \mathrm{L} \mathrm{CaCO}_{3}\right)$ & $24-102$ & $40-90$ & $26-100$ \\
Total organic matter $\left(\mathrm{mg}^{\prime} / \mathrm{L}\right)$ & $0.00002-0.0043$ & $0.00003-0.0026$ & $0.00003-0.00172$ \\
Ammonia $(\mathrm{mg} / \mathrm{L})$ & $0.04-0.39$ & $0.10-0.47$ & $0.01-0.61$ \\
Nitrite $(\mathrm{mg} / \mathrm{L})$ & $0.50-0.70$ & $0.50-0.82$ & $0.50-1.00$ \\
Nitrate $(\mathrm{mg} / \mathrm{L})$ & &
\end{tabular}


the crab (Handeland et al., 2008; Abbink et al., 2011; Gao et al., 2011). Based on the results of the water quality test (Table 2), water quality parameters were still within the recommended ranges for mud crab production. The TOM parameter was observed to be above the optimum range for mud crab culture in all treaments and treatment $\mathrm{A}$ had the highest TOM value (ranged between $24-102 \mathrm{mg} / \mathrm{L}$ ) while the optimal TOM range in water is $20-30 \mathrm{mg} / \mathrm{L}$ (FAO, 2011). In afct, the total organic matter (TOM) content of marine sediment is generally very low (Zamora \& Jeffs, 2011). However, a high range did not affect the rearing media opacities, which was evidenced by the turbidity range that were still within the recommended limits $(<5 \mathrm{NTU})$ in all of the treaments (FAO, 2011). Water turbidity could be due to the dissolved organic matters and pigments caused by the decomposition of organic material (Bhatnagar \& Devi, 2013).

The amount of organic matter contained in the water will also affect the BOD, which is the amount of oxygen used by microorganisms to stabilize organic materials (Varadharajan et al., 2013). BOD is a biological test procedures that measures the oxygen consumed by bacteria during organic matter decomposition. It ranged from 0.0032 to $0.0164 \mathrm{mg} / \mathrm{L}$ in the present stuudy, which was way below the optimal range of $20 \mathrm{mg} / \mathrm{L}$ (FAO, 2011). The low BOD could be a consequence of the degradation of both organic and inorganic wastes carried out by bacteria, which also affect ammonia, nitrite, and nitrate concentration in rearing media. The ammonia concentration in the water is known to infulence the osmoregulation process of crustaceans through the gills and an exposure to high ammonia levels can result in an increment in $\mathrm{Na}+/ \mathrm{K}+-$ ATPase activity in the gill (Romano \& Zeng, 2011). Ammonia accumulation in the hemolymph can affect metabolic processes such as oxygen transport and osmotic pressure balance (Unnikrishnan \& Paulraj, 2010). The oxygen availability at an optimum level, in both rearing containers and filter, increased the success rate of nitrifying bacteria in degrading waste (Schreier et al., 2010). DO level in mud crab rearing containers during the 60 days period in a recirculating system was in accordance the FAO (2011) standard for crabs i.e $>5 \mathrm{mg} / \mathrm{L}$. In addition, ammonia reform process in an environment is strongly influenced by temperature (Zhang et al., 2015), which was observed to be within the normal range for mud crab production in a recirculation system $\left(25-35{ }^{\circ} \mathrm{C}\right)$. Ammonia, nitrite and nitrate contents of the rearing containers were measured and observed to be within the optimal ranges set by FAO (2001), e.i. $<0.01 \mathrm{mg} / \mathrm{L}$ for ammonia, $<0.5 \mathrm{mg} / \mathrm{L}$ for nitrite, and $0.1-1 \mathrm{mg} / \mathrm{L}$ for nitrate.

Total aquaculture waste (input) in a rearing container may lead to a decrease in $\mathrm{pH}$, which corresponds to the equilibrium formula between $\mathrm{pH}$ and ammonia (NH3). The equilibrum states that the amonia level of a given environment will increase along with an increasing $\mathrm{pH}$, and vice versa (Yuechai, 2010). In the present study, the $\mathrm{pH}$ was observed to be lower (4.65 to 7.45) tending to an acid environment that was associated to a low alkalinity level. Water alkalinity refers to as the ability of the water to buffer $\mathrm{pH}$ changes and is part of the measurement of the basal concentration parameters of the water including carbonate, bicarbonate, hydroxide, phosphate, and borate (Ekubo \& Abowei, 2011). The optimal alkalinity for mud crab growth performance is above 80 $\mathrm{ppm}$ and the ideal was determined to be $120 \mathrm{ppm}$ (FAO, 2011). Meanwhile, a low alkalinity level was observed in the present study (from 11.46 to $80.23 \mathrm{mg} / \mathrm{L} \mathrm{CaCO} 3$ ), which could be due to the activity of forming new carapace. One of the effects of stocking mud crab at high densities on production is the competition for feed and space that could lead to stress, which is a physiological response against adverse environmental conditions. Blood glucose level is a parameter that best describe physiological responses in animals when maintaining homeostasis during changes that occur around them (Harianto et al., 2014). The highest glucose level was observed at the beginning of the rearing period, indicating hyperglisemia (indicator for early stress), and progressively decreased, which indicated a decrease in stress throuought the rearing period. The high glucose levels in the rearing containers, ranged between $31-39 \mathrm{mg} / \mathrm{dL}$ among treatments, could be a result of stress and the activity of the crab to maintian a stable body, which needs energy. The energy use could also be derived from blood glucose. When under stress condition, the glucose level in the blood increases due to the stress hormone that inhibits the secretion of insulin. Meanwhile, enzymes in the body proceed to gluconeogenesis, resulting in an increase in blood glucose (Tzafrir \& Schreibman, 2010).

Stoking density determination is of capital importance in mud crab production, since it is related to the competition for both feed and space, which may lead to cannibalism that strongly affects the survival rate. In the present study, no 
significant differences were observed between $\mathrm{P} 1$ and $\mathrm{P} 2$ in terms of survival rate $(\mathrm{P}>0.05)$. However, the number of crabs in each container differed at the end the rearing period (4 crabs in P1 and 7 crabs in P2). The lowest survival rate was observed in $\mathrm{P} 3$ treatment, which could be a consequence of cannibalism in the rearing container. Cannibalism could be defined as a type of predation of a dominant group of crabs on the other crabs. A common strategy used by farmers to overcome cannibalism is the reduction of the stocking density, feeding rate, or rearing the crabs individually (Laranja et al., 2010; Zhao et al., 2015).

Absolute growth rate is another parameter that should be closely monitored in the production process, and is defined as the actual increase in size of an individual per unit time under specific conditions (NRC, 1977). Growth is influenced by both internal and external factors (Sartje, 2010). Internal factors includes the resistance to disease and genetic, while the external factors include the availability of food in the living environment. Based on Table 2, there is no significant differences were observed between $\mathrm{P} 1, \mathrm{P} 2$, and $\mathrm{P} 3$ treatments in absolute growth rate parameter $(0.68 \pm 0.02 \mathrm{~g} /$ crab/day, $0.68 \pm 0.01 \mathrm{~g} / \mathrm{crab} /$ day and $0.66 \pm 0.01 \mathrm{~g} /$ crab/day).

Feed conversion ratio is a ratio measuring the efficiency with which the fish bodies convert animal feed into the desired output (NRC, 1977). During the rearing period, crabs were fed on fresh fish at satiation (Table 2). Analysis of variance showed that stocking density had a significant effect $(\mathrm{P}<0.05)$ on the feed conversion ratio and the best FCR was observed in P2 treatment $(10.11 \pm 0.11)$ support with the best survival rate and total biomass value $(73.33 \pm 5.77 \%$ and $1380.10 \pm 110.04 \mathrm{~g}$ ). The stocking density of $10 \mathrm{crabs} / \mathrm{container}$ showed the best results support with survival rate value indicating that the stocking density is efficient in recirculation system for spesific container.

\section{CONCLUSION}

The best stocking density for mud crab Scylla serrata production is $10 \mathrm{ind} /$ container (P2) with a survival rate of $73.33 \pm 5.77 \%$.

\section{REFERENCES}

Abbink W, Garcia AB, Roques JAC, Partridge GJ, Kloet K, Schneider O. 2011. The effect of temperature and $\mathrm{pH}$ on the growth and physiological response of juvenile yellowtail kingfish Seriola lalandi in recirculating aquaculture systems. Aquaculture 333: 130135.

Bhatnagar A, Devi P. 2013. Water quality guidlines for the management of pond fish cullture. International Journal of Environmental Sciences 3: 1980-2009.

Blaxhall PC, Daysley KW. 1973. Routine haematological methods for use with fish blood. Journal Fish Biology 5: 577-581.

Ekubo AA, Abowei JFN. 2011. Review of some water quality management principles in culture fisheries. Journal Science Engineering Technology 3: 1342-1357.

[FAO] Food and Agriculture Organization of United Nation. 2011. Mud Crab Aquaculture: A Practical Manual. Rome (IT): FAO.

Gao H, Kong J, Li Z, Xiao G, Meng X. 2011. Quantitative analysis of temperature, salinity, and $\mathrm{pH}$ on WSSV proliferation in Chinese shrimp Fenneropenaeus chinensis by realtime PCR. Aquaculture 312: 26-31.

Goddard S. 1996. Feed Management in Intensive Aquaculture. New York (US): Chapman and Hall.

Handeland SO, Imsland AK, Stefansson SO. 2008. The effect of temperature and fish size on growth, feed intake, food conversion efficiency and stomach evacution rate of atlantic salmon post-smolts. Aquaculture 283: 36-42.

Harianto E, Budiardi T, Sudrajat AO. 2014. Growth performance of $3 \mathrm{~g}$ Anguilla bicolor bicolor at different density. Jurnal Akuakultur Indonesia 13: 120-131.

Hastuti YP, Affandi R, Safrina MD, Faturrohman K, Nurussalam W. 2015. Optimum salinity for growth of mangrove crab Scylla serrata seed in recirculation systems. Jurnal Akuakultur Indonesia 14: 50-57.

Hastuti YP, Nadeak H, Affandi R, Faturrohman K. 2016. Optimum $\mathrm{pH}$ determination for mangrove crab Scylla serrata growth in controlled containers. Jurnal Akuakultur Indonesia 15:171-179.

[KKP] Kementrian Kelautan dan Perikanan. 2014. Produksi Benih Kepiting dan Rajungan BPBAP Takalar Mendukung Perikanan yang Berkelanjutan. Jakarta (ID): Direktorat Jenderal Perikanan Budidaya.

Laranja JLQ, Quinitio ET, Catacutan MR, Coloso RM. 2010. Effect of dietary L-tryptophan on the agonistic behavior, groeth, and survival of 
juvenile mud crab Scylla serrata. Aquaculture 310: 84-90.

Mulyadi, Tang U, Yani ES. 2014. Sistem resirkulasi dengan menggunakan filter yang berbeda terhadap pertumbuhan benih ikan nila Oreochromis niloticus. Jurnal Akuakultut Rawa Indonesia 2: 117-124.

[NRC] National Research Council. 1977. Nutrient Requirement of Warmwater Fishes and Shelfishes Revised Edition. Washinton D.C (US): National Academy Press.

Romano N, Zeng C. 2011. Importance of balanced $\mathrm{Na}+/ \mathrm{K}+$ ratios for blue swimmer crabs Portunus pelagicus to cope with elevated ammonia-N and differences between in vitro and in vivo gill $\mathrm{Na}^{+} / \mathrm{K}^{+}$-ATPase responses. Aquaculture 318: 154-161.

Sartje L. 2010. Osmoregulation in aquatic animals. Jurnal Perikanan dan Kelautan 6: 46-50.

Schreier HJ, Mirzoyan N, Saito K. 2010. Microbial diversity of biological filters in recirculating aquaculture systems. Biotechnology 21: 318325.

Siahainenia L. 2009. Inventarisasi jenis, struktur populasi dan potensi reproduksi kepiting bakau Scylla spp. pada ekosistem mangrove desa Passo. Journal of Marine Research 8: 103-110.

Tzafrir PT, Schreibman MP. 2010. Preliminary studies of energy and protein requirements of
Atlantic horseshoe crabs Limulus polyphemus grown in captivity. Journal of the World Aquaculture Society 41: 874-883.

Unnikrishnan U, Paulraj R. 2010. Dietary protein requirement of giant mud crab Scylla serrata juveniles fed iso-energetic formulated diets having graded protein levels. Aquaculture Research 41: 278-294.

Varadharajan D, Soundarapandian P, Pushparajan N. 2013.Effect of physico-chemical parameters on crabs biodiversity. Journal Marine Science Ressearch and Development 3: 1-5.

Yuechai MA. 2010. Effects of $\mathrm{pH}$ challenge on the immune factors of Scylla serrata. College of Life Science and Biotechnology: 479-484.

Zamora LN, Jeffs AG. 2011. Feeding, selection, digestion and absorption of the organic matter from mussel waste by juveniles of the depositfeeding sea cucumber Australostichopus mollis. Aquaculture 317: 223-228.

Zhang S, Li G, Li X, Tao L. 2015. Multiple linear modeling of outflow nitrogen dynamics in vertical-flow constructed wetlands under two different operating states. Ecological Engineering 81: 53-61.

Zhao J, Wen X, Li S, Zhu D, Li Y. 2015. Effects of dietary lipid levels on growth, feed utilization, body composition and antioxidants of juvenile mud crab Scylla paramamosain (Estampador). Aquaculture 435: 200-206. 